American Journal of Applied Sciences 4 (4): 211-214, 2007

ISSN 1546-9239

(C) 2007 Science Publications

\title{
Characteristics of Nitrogen Removal from Old Landfill Leachate by Sequencing Batch Biofilm Reactor
}

\author{
Long Tengrui, Anas F. Al-Harbawi, Lin Ming Bo, Zhai Jun and Xiang Yu Long \\ Faculty of Urban Construction and Environmental Engineering, Chongqing University, China, 400045
}

\begin{abstract}
Municipal landfill leachate is a high strength wastewater characterized by high concentrations of organics and ammonia and potentially containing toxic materials. The paper reports the results of a laboratory scale investigation aimed at evaluating the effectiveness of mature municipal landfill leachate treatment by a biological stage (used SBBR as a biological treatment) to study the nitrogen removal capabilities for treatment of sanitary landfill leachate containing high ammonia concentration. The monitored sample taken from the Chang Sheng bridge landfill site in Chongqing city-China, has its concentrations of $\mathrm{COD}, \mathrm{BOD}_{5}$ and $\mathrm{NH}_{3}-\mathrm{N}$ about 1650,75 and $1100 \mathrm{mg} \mathrm{L}^{-1}$ respectively. The results showed that after two months long period of domestication and one month period of stability, the ammonia nitrogen removal efficiency reached to $99 \%$ in the SBBR reactor, at nitrogen loading rate $0.51 \mathrm{~kg} \mathrm{TN} \mathrm{m}^{-3}$ per day and HRT was $9 \mathrm{hrs}$, met to Chinese standards for discharge.
\end{abstract}

Keywords: Landfill leachate, SBBR, nitrogen removal, biological treatment

\section{INTRODUCTION}

Sanitary landfills have been suggested to be the most economical and environmentally acceptable method for disposal of municipal solid wastes. However, leachate produced from landfills is a high strength organic wastewater which, when discharged directly to a municipal wastewater treatment plant, may cause corrosion of the pump station, difficulty in maintaining constant effluent chlorine residual and sludge bulking and settling problems ${ }^{[1,2]}$. Basically, three phases of decomposition are distinguished for domestic landfills occurring within twenty years, as shown in (Table 1) ${ }^{[3]}$.

Municipal landfill leachates are considered one of the types of wastewater with the greatest environmental impact. The most critical aspects of leachates are linked to the high concentrations of several pollutants. Municipal landfill leachates contain pollutants that can be divided into four main groups: dissolved organic matter; inorganic compounds, such as ammonium, calcium, magnesium, sodium, potassium, iron, sulphates, chlorides; heavy metals, such as cadmium, chromium, copper, lead, nickel, zinc; and xenobiotic organic substances. Organic materials found in landfill leachates are typically volatile fatty acids and humic and fulvic compounds. Xenobiotic organic compounds coming from household or industrial chemicals are

\begin{tabular}{|c|c|c|c|}
\hline leachate type & Young & Intermediate & Stabilized \\
\hline Landfill age yr & $<5$ & $5-10$ & $>10$ \\
\hline $\mathrm{pH}$ & $<6.5$ & 7 & $>7.5$ \\
\hline COD g L ${ }^{-1}$ & $>20$ & $13-15$ & $<2$ \\
\hline $\mathrm{BOD} / \mathrm{COD}$ & $>0.3$ & $0.1-0.3$ & $<0.1$ \\
\hline TOC/COD & 0.3 & - & 0.4 \\
\hline Organic matter & $70-90 \%$ VFA & $20-30 \%$ VFA & HMW \\
\hline Nitrogen & \multicolumn{3}{|c|}{$100-2000 \mathrm{mg} \mathrm{L}^{-1} \mathrm{TKN}$} \\
\hline Metals $\mathrm{g} \mathrm{L}^{-1}$ & 2 & $<2$ & $<2$ \\
\hline
\end{tabular}

present in very low concentrations (usually lower than 1 $\mathrm{mg} \mathrm{L}^{-1}$ ). These compounds include among others a variety of aromatic hydrocarbons, phenols, chlorinated aliphatics, pesticides and plastizers ${ }^{[4]}$.

Landfill leachate must be collected and appropriately treated before being discharged into the environment ${ }^{[5]}$. Satisfactory treatment of leachate is thus no easy task ${ }^{[6]}$ and the biological treatment is the most economically efficient method for the removal of biodegradable organic compounds ${ }^{[4]}$. Several biological treatment systems have been used such as the anaerobic pond, oxidation pond, trickling filter, the combined trickling filter and activated sludge system. However, each system had disadvantages. The aerated lagoon required a greater area and the effluent quality fluctuated. The anaerobic pond produced a bad smell caused by $\mathrm{H}_{2} \mathrm{~S}$ and $\mathrm{NH}_{3}$. The activated sludge system consumed a high amount of energy and the biosludge was often raised and bulked in the clarifier. The SBR

Corresponding Author: $\quad$ Long Tengrui, Faculty of Urban Construction and Environmental Engineering, Chongqing University, China, 400045 
system might be suitable to reduce nitrogen compounds by nitrification and denitrification, but the SBR system still has some disadvantages such as the high excess sludge produced and the high sludge volume index ${ }^{[7]}$. However, in the case of organic compounds with a low biodegradability, when specialized organisms are required, or when a decrease the $\mathrm{BOD}_{5} / \mathrm{COD}$ ratio of wastewater is practical the Sequencing batch biofilm reactor (SBBR) system is preferable ${ }^{[8]}$. The SBBR (sequencing Batch Biofilm Reactor) process strategy is characterized by a controlled periodic change of process conditions such as concentration of oxygen and other biological reactants (e.g., substrate and inorganic nutrients). These environmental conditions are controlled using fill and draw operations at distinct time intervals. Application of periodic process conditions allows the development of the desired consortium of microorganisms in a single reactor. An SBR system can be operated as an activated sludge reactor (SBR-AS) or as a biofilm reactor (SBBR) packed with any support material to serve as a substratum for microorganism growth $^{[8]}$. The Sequencing batch biofilm reactor (SBBR) is also used to biologically treat wastewater containing volatile waste components, dilute solutions or those requiring maintenance of slow growing consortium ${ }^{[9]}$.

The objective of this investigation is to study of using the SBBR system to remove the ammonia as a biological treatment of landfill leachate and to meet with standards.

\section{MATERIALS AND METHODS}

The leachate investigated in this experiment was taken from the ChangSheng Bridge Landfill inside Chongqing city. The composition can be showed in Table 2.

From Table 2, the landfill leachate is characterized as low $\mathrm{C} / \mathrm{N}$ ratio, low $\mathrm{BOD}_{5} / \mathrm{COD}$ ratio and high contents of $\mathrm{NH}_{3}-\mathrm{N}$ (1100 mg L ${ }^{-1}$ ), which show the leachate can be classified as "old" and nonbiodegradable.

The investigation has been carried out by a labscale SBBR made of a cylindrical reactor (geometric volume $24 \mathrm{~L}$, working liquid volume $12 \mathrm{~L}$ ). The SBBR reactors (12 1 capacity) were made from acrylic plastic ( $5 \mathrm{~mm}$ thick). The dimensions of the reactor were 0.29 $\mathrm{m}$ (diameter) by $0.35 \mathrm{~m}$ (height). Air pump was used for supplying air for the reactor. The air diffuser for aeration was set up on the top of the settling zone to allow the biomass of large aggregates detached from the biofilm to settle during the aeration. The packing ratio of the carriers was $30 \%$.
Table 2: The Composition of the investigated landfill leachate

\begin{tabular}{lll}
\hline Parameter & Unit & Value \\
\hline $\mathrm{COD}$ & $\mathrm{mg} \mathrm{L}$ & 1650 \\
$\mathrm{BOD}_{5}$ & $\mathrm{mg} \mathrm{L}$ & 75 \\
$\mathrm{NH}_{3}-\mathrm{N}$ & $\mathrm{mg} \mathrm{L}$ & 1100 \\
$\mathrm{TN}$ & $\mathrm{mg} \mathrm{L}^{-1}$ & 1350 \\
$\mathrm{PO}_{4}-\mathrm{P}$ & $\mathrm{mg} \mathrm{L}^{-1}$ & 12 \\
$\mathrm{SS}$ & $\mathrm{mg} \mathrm{L}^{-1}$ & 100 \\
$\mathrm{pH}$ & $\mathrm{mg} \mathrm{L}^{-1}$ & $8 \sim 9$ \\
\hline
\end{tabular}

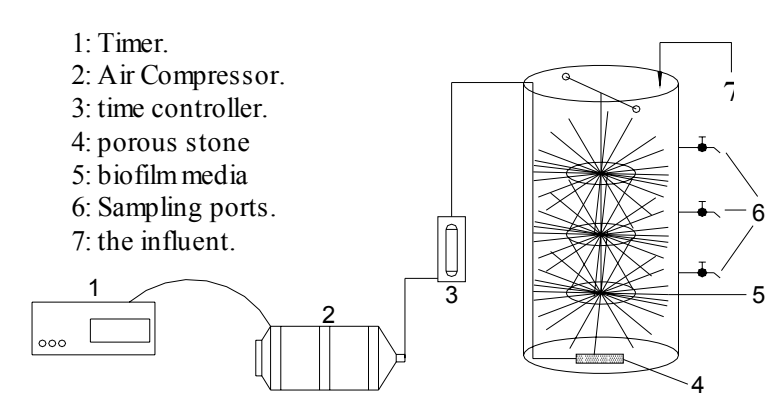

Fig. 1: Schematic diagram of the SBBR system

Figure 1 represents schematic diagram of the experimental apparatus. Units of fibrous carriers hung uniformly from the top of the reactor. Each unit of the fibrous carriers consisted of many bunches of fibers. The 24 hrs operation cycle comprised a 30 min filling period, during the acclimatization period.

\section{RESULTS AND DISCUSSION}

Performance of SBBR: During the acclimatization period, we studied the effect of chemical addition, temperature and biofilm density on the performance of SBBR. We observed that $\mathrm{pH}$ - value inside the SBBR decreased with time for each cycle, lead to a negative effect on the ammonia removal; therefore we added 1 mol L ${ }^{-1}$ of the alkalinity (used $\mathrm{Na}_{2} \mathrm{CO}_{3}$ as an alkalinity) two times for each cycle to keep the $\mathrm{pH}$-value more than 7.0, as shown in Fig. 2.

The temperature affected on the SBBR performance as shown in Fig. 3, we observed that when temperature inside the reactor increased, more ammonia removal achieved, because the microorganisms prefer the high temperature (between $30-33^{\circ} \mathrm{C}$ ).

From the Fig. 4 we demonstrated that when increased the biofilm density lead to more ammonia removal.

Use of SBBR system to remove ammonia $\left(\mathrm{NH}_{3}-\mathrm{N}\right)$ as a biological treatment of the old landfill leachate: Each cycle of the SBBR was divided into fill, react and draw periods. The react time for each cycle was the total cycle time less $1 / 2$ hour for the fill and draw time 
Am. J. Applied Sci., 4 (4): 211-214, 2007

Table 3: operation conditions for the SBBR for ammonia removal

\begin{tabular}{|c|c|c|c|c|c|c|}
\hline HRT(h) & Loading rate $\mathrm{kg} /\left(\mathrm{m}^{3} \cdot \mathrm{d}\right)$ & \multicolumn{2}{|c|}{ Biofilm density to the total density } & Effluent volume (L) & Temp. $\left({ }^{\circ} \mathrm{C}\right)$ & Total volume (L) \\
\hline 9 & 0.51 & & $42 \%$ & 2 & $30-33$ & 12 \\
\hline Time (hrs) & $\mathrm{pH}$ & $\mathrm{NH}_{3}-\mathrm{N}\left(\mathrm{mg} \mathrm{L}^{-1}\right)$ & $\mathrm{NO}_{2}-\mathrm{N}\left(\mathrm{mg} \mathrm{L}^{-1}\right)$ & $\mathrm{NO}_{3}-\mathrm{N}\left(\mathrm{mg} \mathrm{L}^{-1}\right)$ & $\mathrm{TN}\left(\mathrm{mg} \mathrm{L}^{-1}\right)$ & $\mathrm{DO}\left(\mathrm{mg} \mathrm{L}^{-1}\right)$ \\
\hline 0 & 8.61 & 121.275 & 89.90838 & 730 & 1248.5 & 4.7 \\
\hline 2 & 8.34 & 98 & 79.92738 & 705 & 1243 & 4.7 \\
\hline 3 & 8.1 & 83.3 & 93.65125 & 860 & 1259.5 & 4.7 \\
\hline 4 & 7.91 & 66.64 & 96.97825 & 900 & 1245.75 & 4.6 \\
\hline 5 & 7.68 & 49 & 89.90838 & 1005 & 1240.25 & 4.6 \\
\hline 6 & 8.62 & 40.425 & 74.521 & 982.5 & 1239.5 & 4.5 \\
\hline 7 & 7.82 & 33.565 & 59.5495 & 1092.5 & 1235.75 & 4.5 \\
\hline 8 & 7.7 & 20.09 & 41.66688 & 1152.5 & 1233.25 & 4.7 \\
\hline 9 & 7.64 & 14.7 & 22.9525 & 1145 & 1228.75 & 4.8 \\
\hline 10 & 7.52 & 12.74 & 15.46675 & 1137.5 & 1225 & 4.7 \\
\hline 11 & 7.43 & 11.025 & 11.308 & 1157.5 & 1219.5 & 4.9 \\
\hline
\end{tabular}

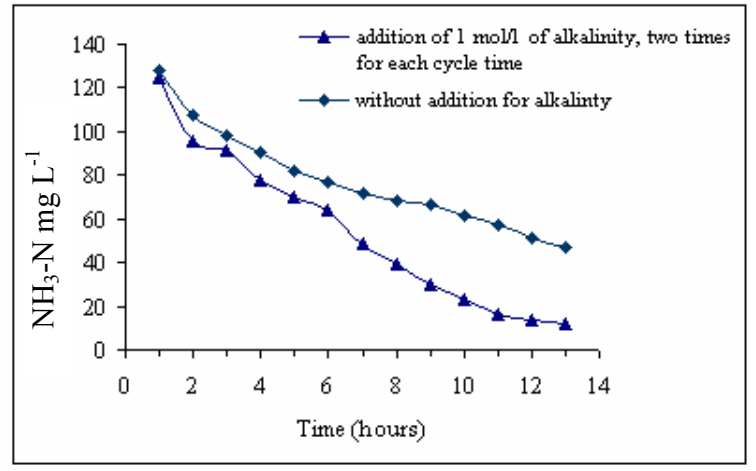

Fig. 2: Effect of alkalinity addition on the SBBR performance

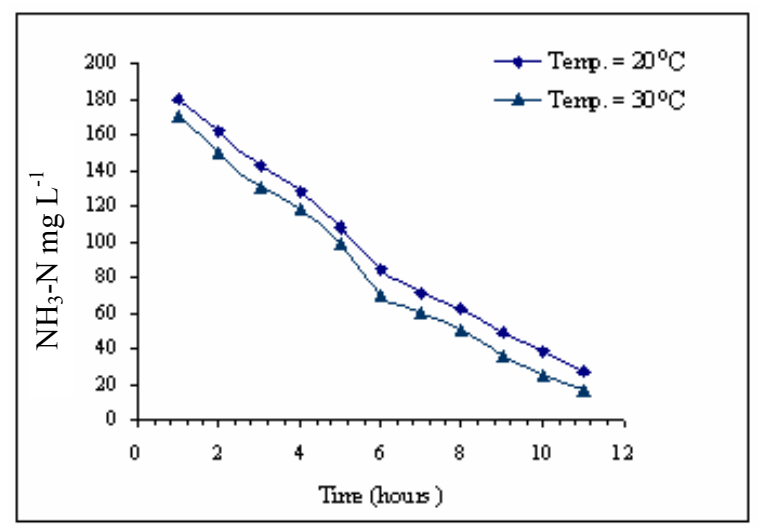

Fig. 3: Effect of temp. on the SBBR performance

(30 min). After 2 months acclimatization with a Nitrogen loading rate of $0.41 \mathrm{~kg} \mathrm{TN} \mathrm{m}^{-3}$ per day, the SBBR had reached a steady state. Then cycle time was reduced from 24 to $9 \mathrm{hrs}$ and the loading rate from 0.41 to $0.51 \mathrm{~kg} \mathrm{TN} \mathrm{m}^{-3}$ per day. The data obtained from the operation of the SBBR at the last cycle time are summarized in Table 3 and 4.

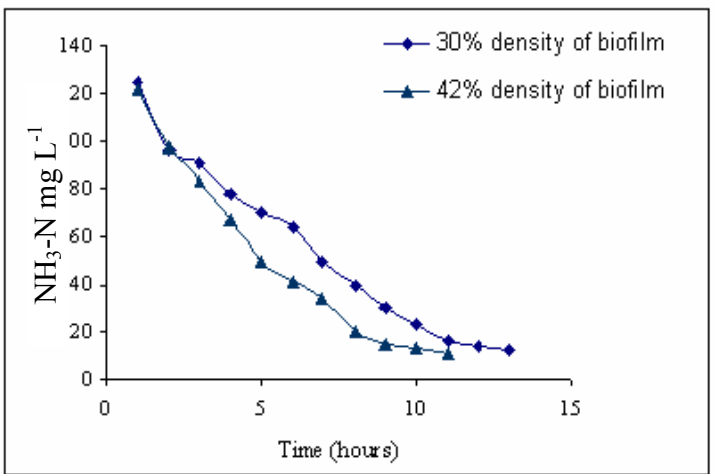

Fig. 4: Effect of biofilm density on the SBBR performance

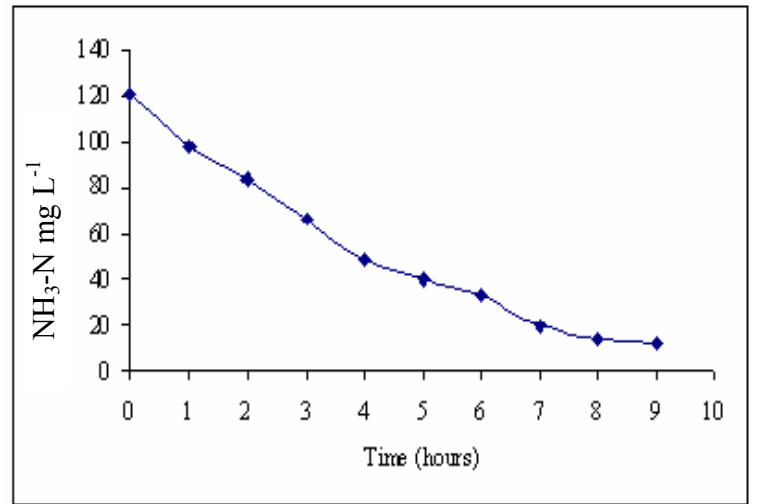

Fig. 5: The change of ammonia with time at the last cycle

During the reaction, the concentration of the $\mathrm{NH}_{3}$ $\mathrm{N}$ decreased gradually in the reactor until reached to 11 $\mathrm{mg} \mathrm{L}^{-1}$ as shown in Fig. 5.

In Fig. 6 observed that there was accumulation of nitrite significantly in the first $3 \mathrm{hrs}$, the concentration 
of nitrite $\left(\mathrm{NO}_{2}\right)$ inside reactor increased with time and this point represents the maximum of nitrite

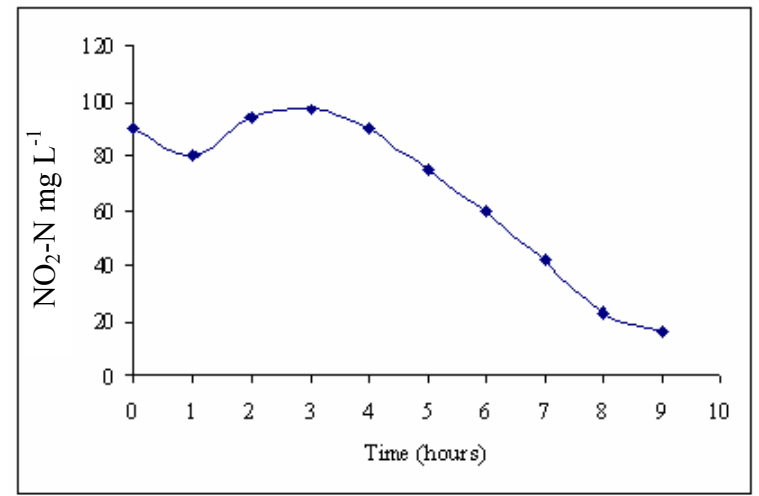

Fig. 6: The change of the nitrite with time at the last cycle

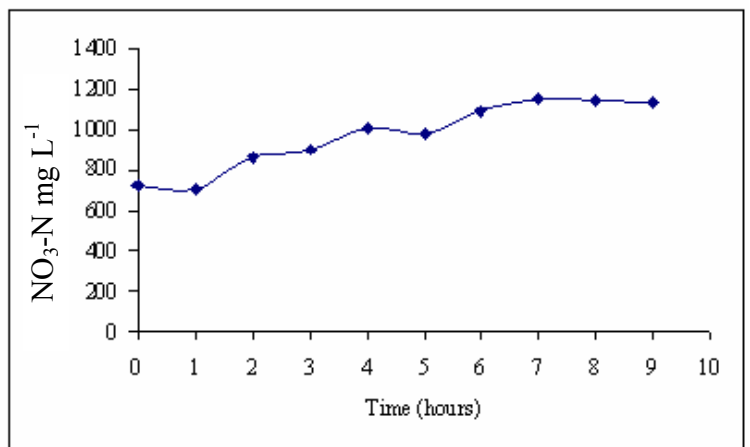

Fig. 7: The change of the nitrate with time at the last cycle

concentration. After that the nitrite was converted through reaction and decreased with time. The reason of the nitrite accumulation was the presence of a lot of free ammonia inside the SBBR reactor restrained the nitrifier bacteria.

In Fig. 7 we observed that the concentration of nitrate $\left(\mathrm{NO}_{3}\right)$ increased gradually, because the ammonia nitrogen inside the reactor was removed under thorough aeration and there was no denitrification.

\section{CONCLUSION}

The landfill leachate obtained from an old municipal landfill was treated using SBBR system as a biological treatment. Based on the results obtained from tests, the optimum operating conditions were identified. The tests results revealed the following informations:

1. The landfill leachate is characterized as low $\mathrm{BOD}_{5} / \mathrm{COD}$ ratio was about 0.05 and high contents of $\mathrm{NH}_{3}-\mathrm{N}\left(1100 \mathrm{mg} \mathrm{L}^{-1}\right)$, which show the leachate, can be classified as "old" and non-biodegradable.
2. The SBBR was shown to be a viable reactor system for treating the leachate. The laboratory study on the sequencing batch biofilm reactor (SBBR) resulted in the following conclusions:

3 The SBBR can remove the ammonia effectively using adequate operation conditions.

4. The highest ammonia removal was obtained with a nitrogen loading rate of $0.51 \mathrm{~kg} \mathrm{TN} \mathrm{m}^{-3}$ per day and cycle time at $9 \mathrm{hrs}$.

5. The ammonia removal percent after treatment was $99 \%$, or $11 \mathrm{mg} \mathrm{L}^{-1}$ and met with Chinese standards for discharge.

\section{REFERENCES}

1. O'leary, P.R., G. Tchobanoglous and F. Kreith (Eds.), 2002. Handbook of Solid Waste Management. McGraw-Hill, United States.

2. Ehrig, H., R. Stegmann, T.H. Christensen and R Cossu, 1992. Stegmann, Landfilling of Waste: Leachate. 1st Edn., Elsevier Applied Science, London and New York.

3. Lema, J.M., R. Mendez and R. Blazquez, 1988. Characteristics of landfill leachates and alternatives for their treatment: A review. J. Water, Air and Soil Pollution, 40: 223-253.

4. Claudio Di Iaconi, R. Ramadori and A. Lopez, 2006, Combined biological and chemical degradation for treating a mature municipal landfill leachate. Biochem. Engg. J., 31: 118-124.

5. Loukidou, M.X. and A.I. Zouboulis, 2001. Comparison of two biological treatment processes using attached-growth biomass for sanitary landfill leachate treatment. Environmental Pollution, 111: 273-281.

6. Sheng, H.L. and C.C. Chang, 2000. Treatment of landfill leachate by combined electro-Fenton oxidation and sequencing batch rector method. Water Res., 34: 4243-4249.

7. Suntud, S., N. Jeeyachokb and R. Larplaia, 2005, Sequencing batch reactor biofilm system for treatment of milk industry wastewater. J. Environ. Manag., 76: 177-183.

8. Dollerer, J. and P.A. Wilderer, 1996. Biological treatment of leachates from hazardous waste landfills using SBBR technology. Waste Sci. Tech., 34: 437-444.

9. Daniel, M., White and William Schnabel, 1998. Treatment of cyanide waste in a sequencing batch biofilm reactor. Water Res., 32: 254-257. 